This work is licensed under a Creative Commons Attribution 4.0 International License.

Ovaj rad dostupan je za upotrebu pod licencom Creative Commons Imenovanje 4.0 međunarodna.

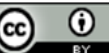

Boris BOSANČIC

Filozofski fakultet

Sveučilišta J. J. Strossmayera u Osijeku

Lorenza Jägera 9

HR - 31000 Osijek

bbosancic@ffos.hr
UDK 141.78 Derrida, J.

1:62 Foerster, $\mathrm{H}$. von

1:53 Heisenberg, W.

DOI: https://doi.org/10.29162/ANAFORA.v5i1.1

Izvorni znanstveni članak

Original Research Article

Primljeno 25. listopada 2017.

Received: 25 October 2017

Prihvaćeno 10. svibnja 2018.

Accepted: 10 May 2018

\title{
ZAŠTO NAŠE ISKUSTVO ZAPOČINJE IZ SREDINE? O TRI „MEDITACIJE O POSREDOVANOM ISKUSTVU“
}

\section{Sažetak}

U radu se s jednoga osobitog stajališta, koje zahvaća u nekoliko područja ljudskog znanja i djelatnosti, nastoji ukazati na moguće izvore našega iskustva koji se temelje na znakovima i relacijama između znakova, kao i na procesu pridavanja značenja. Kroz pomno odabrane teorijske pristupe i tradicije mišljenja koji porijeklo vuku iz različitih područja znanosti, u radu se nastojala elaborirati i potvrditi glavna teza: da naše iskustvo započinje iz sredine i da je, kao takvo, uvijek posredovano; bilo označiteljima kako se tvrdi u poststrukturalističkoj teoriji pisma Jacquesa Derridaa, bilo procesom pridavanja značenja u konstruktivističkom pristupu kognitivnome procesu Heinza von Foerstera ili pak putem samog označenoga kao pojave koja u eksperimentima kvantne fizike nastaje tek samim činom motrenja, a što prejudiciraju filozofske implikacije kvantne teorije Wernera Heisenberga. 
Ključne riječi: znak, označitelj, označeno, poststrukturalizam, Jacques Derrida, konstruktivizam, Heinz von Foerster, kvantna teorija, Werner Heisenberg

\section{Uvod}

Znak kao predmet proučavanja različitih znanstvenih disciplina - ali prije svih lingvistike, i iz nje proizišle semiotike - privukao je veću pozornost znanstvenika tek nakon razvoja strukturalističkog pristupa ovim pitanjima švicarskog jezikoslovca Ferdinanda de Saussurea. Različite tradicije mišljenja pristupaju znaku kao izvornome fenomenu svekolikog iskustva na različite načine, ali većina njih, slaže se da znak, u načelu, upućuje ili reprezentira nešto drugo, u teorijskom diskursu - označeno. Međutim, Charles Sanders Peirce, američki filozof i, po mnogima, prvi semiotičar, koji je živio još u 19. stoljeću, tvrdio je da znak može uputiti jedino na drugi znak te da je, u skladu s tim, svemir prožet znakovima, a sâm čovjek također znak (usp. Nöth 2004: 62). Prema tom pogledu, semiotika kao znanost o znakovima i znakovnim procesima razotkriva se kao „stanovita univerzalna znanost“ (Nöth 2004: 62). ${ }^{1}$ Nešto možemo spoznati jedino putem i preko znakova; $u$ isto vrijeme, svi zakoni prirode bili bi izraženi isključivo znakovima. Upravo taj pogled, po kojemu svaki znak 'stoji' za neki drugi znak, i po kojemu samo označeno ostaje u tami, dok se odnosi, relacije očituju kao primarni za našu spoznaju, povod je ovome radu te će se nastojati propitati kroz usporedbu tri različita teorijska pristupa i tradicije mišljenja koje na nju upućuju: Derridaovu poststrukturalističku teoriju pisma, konstruktivistički pristup kognitivnom procesu Heinza von Foerstera te filozofske implikacije kvantne teorije Wernera Heisenberga.

\footnotetext{
Tvrdnja po kojoj svaki znak samo upućuje na drugi znak postaje razumljivijom ako se prouči Peirceova fenomenologija na kojoj je zasnovao vlastiti pansemiotički pogled na univerzum. Naime, Peirce razlikuje tri kategorije ili načina bivanja nekog uočenog fenomena. Najprije, fenomen može bivati na način da jednostavno jest bez odnošenja prema bilo čemu drugome. Drugi aspekt njegova bivanja manifestira se kroz relaciju, neeksplicitni odnos s drugim fenomenima. Napokon, tek treći aspekt bivanja obuhvaća znakove kao takve, te se odnosi na mogućnost izražavanja bilo kojeg svojstva ili aspekta povezanog uz promatrani fenomen, kao i njegova odnošenja prema drugome fenomenu; osim toga, ovaj način bivanja fenomena uključuje i sve oblike posredovanja, izvođenja zakonitosti, komuniciranja i sl. (usp. Nöth 2004: 62).
} 
Samu strukturu znaka Peirce je izražavao stanovitom trijadom u kojoj je razlikovao reprezentamena ili nositelja znaka, predmet na koji se znak odnosi te interpretanta koji se odnosi na značenje toga znaka (usp. Nöth 2004: 62). U kasnijoj literaturi, izvorna Peirceova trijada doživjela je izmjene i danas se najčešće predstavlja tzv. semiotičkim trokutom koji se pak sastoji od nositelja znaka ili označitelja, objekta znaka ili označenoga te procesa označivanja (ili pridavanja značenja), odnosno interpretacije relacije nositelja znaka i objekta znaka (usp. Nöth 2004: 62).

Pomno odabranim teorijskim pristupima i tradicijama mišljenja koji svoje porijeklo vuku iz različitih područja znanosti, rad će nastojati pokazati da je svaka sastavnica navedenoga „semiotičkog trokuta“ posredovana u spoznajnom smislu, odnosno da se zbilja ne može neposredno iskusiti, što daje za pravo Peirceovoj tezi da svaki znak može upućivati samo na drugi znak. Pritom, sva tri teorijska pristupa, bez obzira na to što dolaze iz potpuno različitih područja znanosti (humanističkih, društvenih, tehničkih i prirodnih znanosti), i što rabe različitu terminologiju te se bave naoko različitim problemima, zagovaraju istu tezu: naše iskustvo započinje iz sredine, i kao takvo, uvijek je posredovano, bilo oznaciteljima, kako se to tvrdi u u Derridaovoj poststrukturalističkoj teoriji pisma, bilo procesom pridavanja značenja koji rezultira samo osobitim „opisom realnosti“, a ne i „uvidom u realnost“, u konstruktivističkom pristupu Heinza von Foerstera, ili se pak to događa putem samog označenoga kao pojave koja u eksperimentima kvantne fizike praktički nastaje tek samim činom motrenja.

Prema navedenim teorijskim pristupima, naše iskustvo, i proizišlo znanje na njemu, ne počivaju isključivo na podacima istraživanja mjernih uređaja, kao ni na interpretaciji, odnosno značenju koje pridajemo tim podacima. Sami za sebe oni nisu dovoljni da bi objasnili što se zapravo događa u „susretu“ ljudskog uma i njegove okoline. Samo u međusobnoj korelaciji, podaci znanstvenih istraživanja $u$ danom značenjskom kontekstu rezultiraju smislenom slikom našeg iskustva. Prihvaćanje jednoga, osobitoga, širega relacijsko-konstruktivističkog pristupa ovim problemima, a koji svoj izvor na komplementaran način pronalazi u humanistici, kognitivnoj znanosti, kibernetici i kvantnoj fizici, možda bi dovelo i do zbližavanja dva, danas sve udaljenija, znanstvena „tabora“, odnosno područja - STEM (Science, 
Technology, Engineering i Mathematics) i SSH (Social Sciences and Humanities) - a o čemu se i u literaturi u posljednje vrijeme sve više diskutira (usp. Oraić Tolić 2011: 71).

\section{1. „Naše iskustvo počinje iz sredine“ - poststrukturalistički pristup Jacquesa Derridaa}

Sposobnost percipiranja uočenih razlika, odnosa među njima, te pridavanje značenja uočenim razlikama katkad se čine nedokučivima za svaku teoriju. Pogotovo se to odnosi na pojam značenja. Prema Greimasu i Courtésu, koje citira (i parafrazira) Nöth:

...o značenju [se] ne može reći ništa, ne ushtjednu li se uvesti metaforičke pretpostavke s mnogim daljnjim implikacijama.

Umjesto značenja postoje samo njihovi učinci, koji se "proizvode s pomoću naših osjetila stupe li u doticaj sa značenjem“, i taj je efekt značenja ,jedina dokučiva zbiljnost, ali zbiljnost koju nije moguće razabrati neposredno“. (Nöth 2004: 149) (Greimass \& Courtésu 1979: 298)

Upravo ta nemogućnost da zbilju dohvatimo neposredno, a koju zagovaraju pojedini teoretičari iz različitih područja znanosti, prema našemu mišljenju, u prvi plan postavlja upravo označitelja, odnosno znak kao takav, dok, s druge strane, označeno, „vanjski svijet“, padaju u drugi plan.

Francuski filozof Jacques Derrida na suptilan je način ukazao na granice našega jezika, koje su uvijek i nepovratno uvjetovane pismom, običnim znakom, a ne „živom riječi“, govorom, idejom, i čija se vjerodostojnost opravdavala njihovom naoko očevidnom prisutnošću u zbilji (odatle izraz „metafizika prisutnosti“) koju je, kao što je to poznato, oduvijek zagovarala većina filozofa Zapadnog kruga. Nasuprot tomu, naše iskustvo započinje uvijek iz sredine (usp. Derrida 1976: 206), tvrdi Derrida, i uvijek posrednikom (tek kasnije, on će uvesti profinjeniji pojam nadomjeska za zbilju (usp. Derrida 1976: 200), i taj je posrednik znak, a nikako logos ili bitak, koji predstavlja samo ljudski otisak svojevrsnoga traga utemeljenog na razlici. Čista neposrednost ne postoji; „stvarnost“, „zbilja“ uvijek su 
izvedene (usp. Derrida 1976: 206). Ključni pojmovi Derridaova diskursa su, dakle, osim pisma - razlika, trag, znak. ${ }^{2}$ Ipak, da tu, doista, nije riječ o nekoj novoj metafizici, već prije sudbinskoj nemoći spram dosezanja nekakvog konačnog znanja, treba pažljivo iščitati što o tomu kaže sam autor:

Ovaj zajednički korijen, koji i nije korijen, već zakrivanje izvorišta, i nije zajednički, jer se vraća samo dosadnom upornošću razlike, ovo neopisivo kretanje same razlike koju smo strateški nazvali tragom, granicom, ili razlikom, može se nazvati pismom samo u povijesnoj ograničenosti, tj. u granicama znanosti i filozofije. (Derrida 1976: 128)

Prema tome, Derridau nije bila namjera stvoriti nekakvu novu metafiziku, a onima koji mu spočitavaju da se i njegov tekst može na isti način "dekonstruirati“ kao što on to čini čitanjem drugih tekstova (ponajviše Heideggera, Rousseaua, Levi-Straussa i dr.) mora postati jasno da on pozorno i dosljedno rabi jezik da bi pomoću njega samo „strateški“ opisao nešto što je samo „neopisivo“ po sebi, što je samo trag... ili razlika... a možda i jedno i drugo! Kad dođemo do pisma, mi smo već u omčama znanosti i filozofije, koje su, paradoksalno, neovlaštene baviti se onime što mu prethodi:

Tu je odista potrebno razumjeti ovu neovlaštenost znanosti koja je i također inkompetencija filozofije, zatvorenost episteme. [Jer] posebno one ne žele vraćanje predznanstvenom ili nižem filozofskom obliku govora. (Derrida 1976: 128)

Dakle, kada se započne raspravljati o razlici, tragu, uvjetima samog pisma, a odatle i same znanosti i filozofije, mora se, paradoksalno, izići iz tradicionalne znanosti i filozofije, a što nijednom znanstveniku i filozofu, koji je čvrsto ukorijenjen $u$ toj tradiciji, zasigurno ne može biti

Ovim pojmovima M. Krivak će pridodati i brazdu, biljeg, rasutost, presijecanje, odgađanje smisla, a posebice pojam pluraliteta. Osim toga, pozivajući se na W. Welscha, istaknut će da je kod ovoga „radikalnog anti-metafizičara“ (J. Derridaa) smisao istine uvijek rasut. „Mnoštvu jedinstva... uvijek prethodi kretanje razlika“ (Krivak 2012: 30). 
podrazumijevajuće, barem ne u početku. ${ }^{3}$ Čini se da ni samom francuskom filozofu, barem u početku, nije bilo potpunoma jasno što je to što bi se trebalo zasnovati, ali mu je barem dao naziv - gramatologija. Gramatologija bi bila znanost o uvjetima episteme per se! Za gramatologe, dosadašnje mišljenje trebalo bi biti:

...jedno neutralno ime, bjelina u tekstu, nužno neodređeno kazalo jednog doba... Na određeni način, „mišljenje“ ne znači ništa... Misliti znači ono što mi još nismo otpočeli činiti: ono što, po mjerilu pisma, otpočinje samo u episteme. (Derrida 1976: 129)

Razliku, kao pojam, Derrida pak pojašnjava sjajnom usporedbom Dionisa kao čiste snage i Apolona, preteče i predstavnika vidljive „svjetske strukture“:

Nesuglasje (le differend), razlika (la différence) između Dioniza i Apolona, između poleta [snage, života] i strukture, ne briše se u povijesti, jer ona nije u povijesti. Na neki neobičan način, ona je i izvorna struktura: podrijetlo povijesti, sama povijesnost. Razlika naprosto ne pripada ni povijesti ni strukturi. Ako valja kazati, kao što to čini Schelling, da „sve tek je Dioniz“, onda valja i znati - a to znači pisati - da Dioniza, kao čistu snagu, opsjeda razlika [naglasio B. B.]. On vidi i vidljiv je. I bode (sebi) oči. Oduvijek je u vezi sa svojim izgledom, s vidljivom formom, sa strukturom, kao i sa svojom smrću. Takvim se sebi i pokazuje. (Derrida 2007: 31)

Na višim stupnjevima, uvjetno rečeno, percepcije i poimanja zbilje, a kako je već spomenuto, umjesto ,jednostavnog“ znaka, prema Derridau, javlja se njezin suplement ili nadomjestak (usp. Derrida 1976: 185). Ulogu toga suplementa ili nadomjeska za zbilju, Derrida demonstrira dekonstruirajući tekst francuskog filozofa Jeana Jacquesa Rousseaoua iz njegovih Ispovijesti. U svojim Ispovijestima J. J. Rousseau opisuje svoju mladalačku ljubav koju je osjetio prema stanovitoj Madame de Warens u čijoj je kući neko vrijeme

\footnotetext{
Za Žarka Paića, pojam razlike ključan je za cjelokupnu poststrukturalističku teoriju, dok se Derridaov pojam razlike, odnosno „raz-luke“ (diférrance) ponajprije „...odnosi na srodni Heideggerov pojam ontologijske diferencije bitka i bića“" (Paić 2003: 44).
} 
živio u mladosti i koju je zvao „Mama“. Jednu po jednu, navodi on „sve ludosti“ koje bi zbog ljubavi činio kad „Mami“ „više [nije] bio pred očima“. Ljubio bi krevet za koji je znao da je ona u njemu spavala, zavjese i pokućstvo u sobi kad bi pomislio da ih je doticala „njezina lijepa ruka“, pa čak i pod, kad bi se sjetio da je ona po njemu hodala (usp. Derrida 1976: 199)! Različiti predmeti u Maminoj odsutnosti, dakle, igraju ulogu suplementa, odnosno nadomjeska za njezinu prisutnost. Međutim, pokazuje se da se ista potreba za nadomjeskom javlja čak i u njezinoj prisutnosti. Zalogaj koji je Madam de Warens bacila na tanjur na njegovo lažno upozorenje da u njemu vidi vlas, on je „...pohlepno dohvatio i progutao“ (Derrida 1976: 199). Drugim riječima, i u njezinoj prisutnosti, a kako to naglašava i Jonathan Culler $\mathrm{u}$ svojoj analizi Derridaove dekonstrukcije teksta Ispovijesti:

...struktura, potreba za suplementom ostaje istom... i lanac zamjena se može nastaviti. Čak i da ju je Rousseau, kako se kaže, mogao „imati“, opet bi osjećao da mu je izmakla i da se samo može prisjećati ili očekivati je. (Culler 2001: 20)

„Iz ovoga niza suplemenata” piše Derrida, „uočavamo jednu zakonitost: zakonitost beskonačnog lanca koji neizbježno umnožava suplementarna posredovanja koja proizvode smisao upravo one stvari od koje se otklanjaju; iluziju same stvari, neposredne prisutnosti, prvotnog zapažanja“ (Culler 2001: 21) (usp. Derrida 1976: 206). I na ovom mjestu on će ostaviti neizbrisiv trag poststrukturalističke misli u zapadnoeuropskom mišljenju: „Neposrednost je izvedena. Sve počinje iz sredine, i to je ono što je „neshvatljivo razumu“ (Derrida 1976: 206). Na ovaj način, i prema Jonathanu Culleru, dokazano je da je naše iskustvo:

...uvijek posredovano znakovima“, a sam „izvornik“ samo proizvod znakova ili suplemenata... Kada pomislite da ste stigli s onu stranu znakova i teksta, u „samu zbilju“, naići ćete na samo još teksta, još znakova i lanaca suplemenata. (Culler 2001:21) 
$\mathrm{Na}$ kraju ove analize zahvaljujući kojoj smo pokazali na koji to način, u jezičnom kontekstu, naše iskustvo započinje iz sredine, donosimo i Derridaove riječi iz možda najglasovitijeg dijela Gramatologije:

Ono što smo htjeli pokazati... jest to da u onom što se zove stvarni život ovih stvorenja „od krvi i mesa”... nikada nije ništa postojalo osim pisma, suplemenata i zamjenskih označavanja, a koja su mogla izbiti samo u lancu razlikovnih odnosa... I tako u beskonačnost, jer... Priroda, ono što riječi imenuju kao „pravu majku“ itd., [jest] svagda već izvan dohvata i da [nije] nikad [postojala]; [i] da ono što stvara značenje i jezik jest [samo] pismo. (Derrida 1976: 208)

Upravo toj tvrdnji vratit ćemo se u trećem dijelu rada kada budemo govorili o promjenama u osnovama prirodnih znanosti uzrokovanima kvantnom teorijom.

Možemo zaključiti kako je sve ono na što se naš jezik, u dobroj namjeri, oslanjao stoljećima da bi dokazao svoju vrijednost i autentičnost, po Derridau, samo iluzija. Značenje nekog znaka oduvijek se stvaralo tek samim činom pisanja. Logos i istina utvare su na kojima više nije moguće utemeljiti nikakvo značenje. Stoga i nije moguće govoriti o nekoj suvisloj teoriji značenja, jer se sve uvijek svodi na trajni alteritet, trajnu ,igru razlika“. ${ }^{4} \mathrm{U}$ tom turbulentnom svijetu signansa i signatuma, dakako da se stvorilo mjesto za konstruktivistički pogled. ${ }^{5}$ Jer - u „igri“ su ostali samo znakovi.

4 Razmatrajući Derridaovu poststrukturalističku teoriju, N. Miščević primjećuje da „...označeni pojam nikad nije prisutan sam u sebi, u samodostatnoj prisutnosti koja bi upućivala sama na sebe. Svaki je pojam načelno i bitno upisan u neki lanac ili sistem unutar kojega upućuje na neki drugi pojam, na druge pojmove zahvaljujući sustavnoj igri razlika. Takva igra nije više jednostavno pojam već mogućnost pojmovnosti, pojmovnog procesa i sistema uopće“ (Miščević 1981: 63).

5 U svom Akademskom pismu, Dubravka Oraić Tolić piše o epistemološkomu konstruktivizmu kao posljedici nastanka „nove retorike“ u znanosti koja je pak nastala kao odgovor na postmodernističke teorije koje su uzrokovale tzv. znanstvene ratove 1990-ih. I ona razlikuje umjereni od radikalnog epistemološkog konstruktivizma (usp. Oraić Tolić 2011: 64). Po svemu sudeći, znanstveni ratovi su zatim uzrokovali nastanak dubokog ponora između dva znanstvena tabora - STEM i SSH - početkom 21. stoljeća, a koji ni do dan danas nije razriješen (usp. Oraić Tolić 2011: 71). 


\section{2. „Naše iskustvo počinje iz sredine“ - konstruktivistički pristup Heinza von Foerstera}

Konstruktivizam se uobičajeno pojavljuje $\mathrm{u}$ kontekstu drugih znanstvenih područja, kao zaseban pravac mišljenja o znanstvenim problemima kojima se bavi promatrano područje. Konstruktivističko stajalište pronalazimo izvorno u pedagogiji, u okviru teorija učenja (engl. learning theory) (Jean Piaget), zatim u biologiji (Humberto Maturana \& Francisco Varela), psihologiji (Ernst von Glassersfeld), sociologiji (Niklas Luhmann) te naposljetku, kognitivnoj znanosti i kibernetici (Heinz von Foerster). Za potonjeg ujedno možemo reći da je jedan od najutjecajnijih teoretičara konstruktivizma i u ovom poglavlju uglavnom će se slijediti njegov pristup kogniciji, jeziku i općenito (našemu) načinu stjecanja iskustva.

U današnjoj literaturi nailazi se na različite vrste konstruktivizma: radikalni, umjereni, socijalni, kulturalni, kritički i mnoge druge. U filozofiji znanosti, primjerice, Henk van den Belt (2003), slijedeći Roba Hagendijka, razlikuje radikalni i umjereni konstruktivizam (usp. van den Belt 2003: 203). U informacijskoj i komunikacijskoj znanosti istu podjelu spominje i Ian Cornelius (usp. Cornelius 2003: 401), slijedeći Gernota Wersiga (usp. Wersig 1997: 223). Naposljetku, Gordana Dodig-Crnković razvila je posebnu vrstu konstruktivizma koji je nazvala „info-komputacijski konstruktivizam“ (engl. info-computational constructivism) i u kojemu središnju ulogu zauzima pojam informacije (Dodig-Crnković 2014: 223).

Bez ulaženja u dublju analizu konstruktivističkih teorija, navest ćemo samo sljedeći primjer da bismo dočarali stav konstruktivističkog mislioca spram spoznaje „vanjskog svijeta“. Kada prstom dotaknemo stol za kojim sjedimo, senzacija ili osjećaj tvrdoće stola za konstruktivističkog mislioca predstavlja samo posljedicu ili rezultat (engl. outcomes) „fizičke“ interakcije samog stola i našeg prsta. Pritom, on nikada neće reći da je stol „tvrd“, nego da je naše iskustvo doticanja stola polučilo osjećajem „tvrdoće“. Ta, naoko suvišna, pedanterija u izražavanju karakteristična je za konstruktivistički nastrojenoga mislioca, kojom on zapravo razotkriva samu bit konstruktivizma. Naime, ono što primamo iz „vanjskog svijeta“ nije odraz predmeta ili nekakva „opipljiva“ sila koju je taj predmet prenio na nas, nego 
elektrokemijski impuls koji je u stanju samo reprezentirati rezultat, odnosno posljedicu susreta između naših „dijelova tijela“ (u ovom primjeru prsta) i predmeta našeg svakodnevnog iskustva (poput stola). Drugim riječima, naš mozak okružen je elektrokemijskom barijerom koja ga i doslovno štiti od bilo kakvog direktnoga, neposrednog iskušavanja zbilje.

No postavlja se pitanje kako je moguće samo od elektrokemijskih signala u umu stvoriti sliku raznolikog svijeta makroskopskih objekata kojim dominiraju najrazličitije boje i oblici? Odnosno, kako objasniti postojanje drugih ljudi oko nas, istih ovih „subjekata“ „od krvi i mesa“ koji razmišljaju na način možda i sličan našemu? Na ovom mjestu ponovno do izražaja dolazi ona ista osobina našega uma koju Jacques Derrida podcrtava u svojoj Gramatologiji - da umije uspostavljati odnose između uočenih razlika i temeljem te sposobnosti stvarati simbole. Jedino, umjesto slova, kao tipičnih simboličnih tvorevina pisma, u ovom slučaju, na „scenu“ stupaju boje i oblici u prostoru i vremenu. Kao osobiti „osjetilni simboli“, oni ujedno predstavljaju i gradivne blokove „stvari svijeta“, putem kojih je naš um sada u stanju konstruirati i makroskopske objekte našega svakidašnjeg iskustva. Drugim riječima, postojanje stola za kojim sjedimo i nas koji ovo pišemo, samo je izvedeno, na neki način u umu konstruirano (von Foerster 2003: 251), našim osjećajem ili sposobnošću razlikovanja i uspostavljanja odnosa između uočenih razlika. Pritom, boje i oblici kao osobiti „osjetilni simboli“ već su sami tvorevine našega uma, a tamo „vani“ možda su samo elektromagnetski valovi, periodičke varijacije tlaka zraka, sporadične kretnje molekula i sl., kako to u svojim radovima naglašava i H. von Foerster (von Foerster 2003: 215). ${ }^{6} \mathrm{U}$ tom smislu, promatrač ili motritelj (engl. observer), zacijelo središnja figura u konstruktivističkim teorijama (ali i glavna nepoznanica), prije bi se mogao dovesti u vezu s nekom vrstom procesa, kao uostalom i sve druge „stvari“ $i$ „objekti iskustva“, nego s nekakvim „čvrstim identitetom“ poput „ja“ koje u „stvarnosti“, prema konstruktivističkom stajalištu, možda i ne postoji.

\footnotetext{
„...'out there' there is no light and no color, there are only electromagnetic waves; 'out there' there is no sound and no music, there are only periodic variations of the air pressure; 'out there' there is no heat and no cold, there are only moving molecules with more or less mean kinetic energy, and so on. Finally, for sure, 'out there' there is no pain." (von Foerster 2003: 215)
} 
Najčešća pak optužba na račun konstruktivističkog stajališta ona je vezana uz solipsizam, stajalište po kojemu sve što postoji i doslovno postoji u umu promatrača. Međutim, konstruktivisti nikada nisu negirali mogućnost postojanja „vanjskog svijeta“! Oni samo tvrde da slika toga „vanjskog svijeta“, koju nam „isporučuju“ osjetila, ne predstavlja njegov odraz, nego da je ta slika uvelike naša konstrukcija. Sam Heinz von Foerster vjerovao je u postojanje „vanjskog svijeta“, ali taj svijet za njega nije direktno spoznatljiv (von Foerster 2003: 6). Svejedno, u skladu s navedenim, znanje je „slika“ koja reprezentira nešto drugo, a ne „vanjski svijet“ kakav on doista jest (usp. Glasersfeld 1995: 14). Drugim riječima, prema konstruktivističkom stajalištu, sveukupno naše znanje o „vanjskom svijetu“ temeljeno je, odnosno sastavljeno, od znakova; shodno tomu, i znanje je samo znak.

Ako je znak jedini fenomen dostupan u kognitivnom procesu, onda je, prema Heinzu von Foersteru, nemoguće dokazati postojanje „objektivne stvarnosti“. Stoga, nemamo prava pozivati se na "objektivnost svijeta“ u postupku provjere znanstvenih argumenata. Štoviše, naše vjerovanje u objektivnost svijeta smetnja je znanstvenom napretku, a posebice procesu razumijevanja samih sebe (Segal 2001: 14). To je ujedno i glavna točka njegova konstruktivističkog stava. Ako započnemo unaprijed pretpostavljati „objektivnu stvarnost“, ta pretpostavka unaprijed će determinirati naše objašnjenje promatrača (Segal 2001: 14).

Kognitivni proces spoznavanja zbilje, tvrdi H. von Foerster, temeljen je na procesuiranju opisa „realnosti“, a ne uvida u realnost, a što pak jezik postavlja u poziciju primarnog sredstva spoznajnog procesa (von Foerster 2003: 232). Kako se znanstvene istine kazuju jezikom, cilj je formulirati epistemologiju koja će biti u stanju odgovoriti na pitanje: kako se jezik ostvaruje? Prema Lynn Segal, autoru knjige San realnosti (The dream of reality) posvećenu konstruktivističkom učenju Heinza von Foerstera, ,jezik je medij kognitivnog postojanja" (Segal 2001: 6). Sve što se može reći o nečemu, izgovara promatrač (engl. observer) i stoga nam je potrebno proučavanje promatrača (von Foerster 2003: 247), a ne nekakva krajnja spoznaja „vanjskog svijeta“. 
Heinz von Foerster englesku riječ computing rabi u zasebnom značenju reflektiranja, transformiranja, modificiranja itd. opaženih fizičkih entiteta i njihovih simboličkih reprezentacija (von Foerster 2003: 216). Kognitivni proces (kognicija, spoznaja), tvrdi von Foerster, ne odnosi se na neposredno reflektiranje realnosti nego na reflektiranje najboljeg opisa realnosti u tom trenutku (ibid.: 216). Ako je moguće povući analogiju i realnost zamijeniti s označenim, a opis sa znakom, onda se temeljem Peirceove tvrdnje da je ono na što se znak odnosi - označeno - također i ponovno znak, može doći do zaključka da se kognitivni proces odnosi na beskrajno reflektiranje znakova. A to znači, da i prema konstruktivističkom stajalištu - sve počinje iz sredine.

Prema konstruktivističkom stajalištu, koje slijedi pristup $H$. von Foerstera, značenje pojedine uočene razlike počiva na odnosu koji uspostavlja s kakvom drugom razlikom. To ujedno znači da samim razlikama nije moguće pridodati značenje „po sebi“. Između dvije razlike moguće je jedino uspostaviti odnos, relaciju kojom one stječu svoje značenje. Uzmimo jednostavan primjer broja 7 koji je veći od broja 6 i manji od broja 8. Da ne postoje relacije "manji“ i „veći“, jedino što bismo mogli ustvrditi jest, da se broj 7 graficki, odnosno pojavno razlikuje od broja 6 i 8. Istu analogiju možemo slijediti i u prostoru i vremenu. Primjerice, možemo reći da neka stvar poprima svoje značenje u odnosu na neku drugu stvar s obzirom na prostorni smještaj u odnosu na drugu stvar. Pa tako, nešto se u prostoru može nalaziti ispred ili iza nas, lijevo ili desno, gore ili dolje itd. U tom smislu, na primitivnoj značenjskoj razini možemo govoriti o „gornjoj“ i „donjoj stvari“, odnosno da nam neka stvar nešto znači samo u odnosu na svoj prostorni smještaj. Na isti način, neka stvar može prethoditi ili slijediti nakon druge stvari u vremenu itd. Nadalje, sve stvari koje se nalaze ispred nas mogu se grupirati u kategoriju koju možemo nazvati StvariIspredNas, a sve stvari koje se nalaze iza nas u kategoriju StvariIzaNas. $\mathrm{Na}$ ovaj način možemo govoriti o nastanku klasa u tipičnoj ontologiji itd.

Razvojem kognitivne domene promatrača pak uspostavljaju se složenija značenja. Primjerice, u kibernetskom, odnosno računalnom kontekstu, značenje binarnog kôda osim što je utemeljeno na razlici između jedinice i nule kao jednostavnih, temeljnih entiteta binarne notacije, temelji se i na razlikovanju uspostavljenih nizova, odnosno složenih, kompozitnih entiteta koji su sastavljeni od više jedinica i nula. Zapravo, sve stvari, uključujući tu i 
najjednostavnije znakove ili simbole poput slova A, u binarnom kôdu predstavljaju složeni, kompozitni entitet predstavljen određenim nizom jedinica i nula u točnom redoslijedu. Sve to možda je i navelo $H$. von Foerstera da izjavi da su korelacije (engl. correlations) možda „sve što imamo" (Segal 2001: 16). ${ }^{7}$

Usprkos svem naporu da se pronikne u bit značenja, čini se da značenja koja izviru iz relacija među znakovima nisu dovoljna kako bi se objasnila složenija značenja koja se javljaju i u najjednostavnijoj ljudskoj komunikaciji. Drugim riječima, i među konstruktivistima se postavilo pitanje kvalitativne odrednice značenja kao takvoga. $\mathrm{Na}$ koncu, pojavila se zamisao koja se ubrzo oblikovala u pitanje: ne počivaju li značenja svih stvari na unaprijed, od prirode, zadanim primitivnim značenjskim vrijednostima (engl. primitive meaning values). Rad čileanskih biologa Humberta Maturanaa i Francisca Varelaa, osim što je privukao pozornost svojim zaključkom koji se može staviti u krilaticu „živjeti znači spoznavati“ (usp. Maturana \& Varela 1980: 13), ${ }^{8}$ bio je veliki napredak u tom smjeru te je poslužio i kao veliki poticaj razvoju konstruktivističkog mišljenja. Naime, oni su smatrali da je glavna svrha spoznavanja preživljavanje živog organizma u svojoj okolini. To znači da svaki živi organizam unaprijed mora baratati primarnim značenjskim vrijednostima koje su usko vezane uz njegovo preživljavanje (usp. Ashby 1958: 84). U tom smislu, svaki vanjski podražaj na primitivnom stupnju razvoja kognitivne domene može značiti nešto dobro ili pak nešto loše za organizam. Analogno tomu, druge značenjske vrijednosti mogu se izvesti iz prvotnih, poput „ugode“ i „neugode“, „užitka“ i „boli“ i sl. Prema istim teoretičarima, to je onda dovoljno da se iz navedenih značenja izvedu sva druga značenja.

"All we have are correlations' says von Foerster...” (Segal 2001: 16).

„Living as a process is a process of cognition. This statement is valid for all organisms, with or without a nervous system" (Maturana \& Varela 1980: 13). 


\section{3. „Naše iskustvo započinje u sredini“ - o filozofskim implikacijama kvantne teorije Wernera Heisenberga}

Na ovom mjestu, na prvi pogled, može se učiniti neobičnim, pa čak i neprihvatljivim, ako našu „meditaciju“ nad tvrdnjom „naše iskustvo počinje u sredini“ premjestimo u područje prirodnih znanosti i pogledamo možemo li ju dovesti u vezu s Derridaovom "meditacijom“ nad istom rečenicom, kao i onom konstruktivističkog mislioca Heinza von Foerstera. Međutim, čni se da upravo suvremenoj fizici, čiji se razvoj ubrzano događao u prvom kvartalu 20. stoljeća i koji je doveo do stvaranja dvije velike teorije - teorije relativnosti i kvantne teorije - imamo zahvaliti za tu mogućnost. Poglavito kvantna teorija ubrzo je dovela do onoga što će Werner Heisenberg, jedan od zagovornika tzv. Kopenhagenske interpretacije kvantne teorije, u nizu svojih predavanja po njemačkim sveučilištima 1930-ih objediniti pod naslovom Promjene u osnovama prirodnih znanosti (Heisenberg 1998). Isti je autor u godinama poslije Drugog svjetskog rata nastavio promišljati filozofske konsekvence kvantne teorije, održavajući predavanja po cijelom svijetu (uključujući tu i našu zemlju), a posebice su značajna bila ona na škotskom sveučilištu St. Andrews u zimskom semestru 1955./'56. - poznata kao Gifford-Lectures, kasnije objavljena u knjizi Fizika $i$ filozofija (Heisenberg 1997), i koja su, čini se, Heisenberga odvela najdalje u tom smjeru.

Ushtjednemo li se poslužiti izrazom drugog najvećeg zagovornika Kopenhagenske interpretacije kvantne teorije - danskog fizičara Nielsa Bohra - i kvantna teorija, na sebi svojstven način, prema našemu mišljenju, izriče jednu komplementarnu „priču“ - ne samo konstruktivističkoj - nego i poststrukturalističkoj „priči“ koje smo prethodno izložili. ${ }^{9} \mathrm{Ne}$ samo u jeziku, i u općenitoj spoznaji zbilje, nego čak pri percepciji najelementarnijih objekata naše spoznaje - označenoga - poput atoma, moramo krenuti od sredine, jer se neposredno opažanje nekakvoga „stvarnoga objektivnog svijeta" sve više razotkriva kao iluzija.

9 U svojoj knjizi Nesjedinljivo znanje (2004) Tihomir Vukelja ističe da je Bohrova ideja komplementarnog opisa ishodište „kopenhaškoga“ tumačenja kvantne mehanike „u okviru kojeg se potpuni korpus mogućega znanja gradi od uzajamno isključivih, ali jednako nužnih - komplementarnih - iskaza“" (Vukelja 2004: 42). 
Kvantna je teorija, naime, dovela do rezultata da jedan atom nije tvorba dostupna našoj zornoj predodžbi $u$ istom smislu kao neki predmet dnevnog iskustva. Atomu ili, točnije, najmanjoj gradivnoj čestici suvremene fizike, elektronu, prema ovoj teoriji, ne pripadaju više „po sebi“ čak ni najjednostavnije geometrijske ili mehaničke osobine, već ih on ima samo u onoj mjeri u kojoj su dostupne pomoću vanjskih zahvata promatranja. (Heisenberg 1998: 72)

Drugim riječima, možda jezik samo slijedi ograničenja koja nam je već sama „priroda“ zadala pri pokušaju njezina spoznavanja: „Za atom moderne fizike sve su kvalitete izvedene, uopće mu neposredno ne pripadaju materijalne osobine" (Heisenberg 1998: 31). Posljedice toga su više nego očite, i u slučaju kvantne teorije priklanjaju se onom istom zaključku koji su na kraju izveli i Derrida i von Foerster, svaki u svojoj domeni znanja:

Više smo negoli prijašnja znanost svjesni toga da ne postoji nijedna sigurna ishodišna točka od koje bi vodili putovi u sva područja onoga što se dade spoznati, već da svaka spoznaja mora lebdjeti nad nekim beskonačnim ponorom; da stalno iznova moramo započinjati u sredini [naglasio B. B.], kako bismo o zbilji govorili u pojmovima koji tek pomoću svoje primjene postupno poprimaju jedan oštriji smisao... (Heisenberg 1998: 78)

Osim toga, prema Kopenhagenskoj interpretaciji kvantne teorije dovršene 1920-ih sve stvari na ovom svijetu imaju dvojnu prirodu: mogu se tretirati i kao čestice i kao valovi. Ta postavka odnosi se i na svjetlost ${ }^{10}$ i na samu materiju. ${ }^{11}$ Dokaz o jedinstvu materije jedan je od najdubljih nalaza kvantne teorije o zbilji koja nas okružuje. Prema tomu nalazu, uz pomoć dovoljno velike energije bilo koja čestica može se pretvoriti u bilo koju drugu česticu

10 Albert Einstein u svom radu $O$ jednom istraživačkom gledanju na proizvodnju $i$ transformaciju svjetlosti (njem. Über einen die Erzeugung und Verwandlung des Lichtes betreffenden heuristischen Gesichtspunkt) objavljenom 1905. godine pokazao je da svjetlost, pored valne, posjeduje i čestičnu prirodu.

11 Louise de Broglie je 1924. godine u svom doktoratu postavio hipotezu da se elektronima u pokretu mogu pripisati, osim čestičnih, i valna svojstva, a što je ubrzo potvrđeno eksperimentima. 
(Heisenberg 1997). Kada tomu dodamo i Heisenbergovu tvrdnju da čestica kao čestica sva svoja svojstva zadobiva isključivo u činu promatranja, nismo li na najbolji mogući način potvrdili ograničenja koja smo već iznijeli u svom radu, a koja se tiču i jezične uporabe i same percepcije zbilje koja nas okružuje.

Implikacije kvantne teorije zadiru ne samo u jezičnu sferu prirodnih znanosti, nego i u samu srž filozofije znanosti i znanstvene spoznaje. Jedna od njih, posebice neugodna po stare metafizičke pretpostavke ontološke realnosti svijeta, neuvijeno tvrdi da su promatrač i promatrano, u fizikalnom eksperimentu, neodvojivi jedno od drugoga. Drugim riječima, bilo koja opažena pojava, čak i u Kantovu smislu, ne postoji, dok ju promatrač, motritelj, u samom eksperimentu ne opazi. Nada o postojanju nekakve objektivne, ontološke realnosti koja se jednoga dana može u potpunosti spoznati ovom je tvrdnjom, dakako, bila ozbiljno poljuljana. Čak i Kantova ideja „stvari po sebi“ pokazuje se neodrživom u svjetlu implikacija i konsekvenci nalaza kvantne teorije. H. von Foerster također ističe da „stvar po sebi“, nadosjetilno iskustvo, ne postoji. On smatra da je okoliš neovisan o promatraču i vidi ga kako „blijedi“, kao i druge ideje (među kojima i ideja 'stvari po sebi') „čija su značenja izgubljena“ (von Foerster 1984; Qvortrup 1993: 12).

Priroda stvarnosti, koja nas okružuje, naprosto nije takva da se može neposredno iskusiti, ustvrdili su zajednički Bohr i Heisenberg u Kopenhagenskoj interpretaciji kvantne teorije:

Kad hoćemo opisati što se događa u atomskom procesu [fizikalnom eksperimentu na mikroskopskoj razini], moramo poći od toga da se riječi „događa se“ mogu odnositi samo na motrenje, a ne na situaciju između dva motrenja... Ne možemo opisati što se „događa“ između tog motrenja i sljedećeg... [Kvantna teorija] ne dopušta prostornovremenski opis onoga što se događa između dva motrenja. Svaki pokušaj da se nađe takav opis vodio bi do protuslovlja. (Heisenberg 1997: 39)

Prema tom stajalištu, motrenje zbilje igra odlučujuću ulogu u eksperimentu i ono što zagovornici Kopenhagenske interpretacije kvantne teorije predlažu 
jest da se sâm pojam „događanja“ ograniči na motrenje. Po njima, priroda je drugačija u ovisnosti od toga promatramo li ju ili ne. Heisenberg ide još i dalje kada zaključuje: „... ono što motrimo nije priroda sama, nego priroda koja je izložena našem načinu postavljanja pitanja“" (Heisenberg 1997: 43).

$\mathrm{Na}$ ovaj način, uspostavili smo vezu između naoko različitih načina razmišljanja, odnosno teorijskih pristupa, u načelu, o istom problemu, problemu načina stjecanja našega iskustva, a odatle i znanja poststrukturalističke teorije pisma, konstruktivističkog pristupa kognitivnom procesu te filozofskih implikacija kvantne teorije. Za sva tri pristupa, naše iskustvo započinje iz sredine, za sva tri pristupa, razlike prevedene u znakove, odnosno pojave, i relacije između njih stoje u temelju. Osim toga, pretpostavili smo, a zatim i elaborirali, na koji način razlike prevedene u znakove, odnosno pojave, svoje značenje mogu uspostaviti $u$ odnosu na druge razlike, odnosno znakove u okruženju.

\section{Zaključak}

Znakovi kao simbolizirane razlike, izvor su bezgraničnih mogućnosti pridavanja značenja možebitno mnogo prozaičnoj zbilji koja stoji u njihovoj pozadini. Svjetonazor koji zagovara takvu sliku poznat je u literaturi pod nazivom konstruktivizam. Ako, pritom, znak kao takav može upućivati jedino na drugi znak, a što je stajalište semiotičara C. S. Peircea, onda je svo naše iskustvo isključivo posredovano znakovima, a sama neposrednost, prema poststrukturalističkom misliocu Jacquesu Derridau, uvijek izvedena. U radu se, stoga, nastojao potkrijepiti stav da naše iskustvo može započeti jedino iz sredine, i da jedino na taj način može osigurati bogat raspon različitih interpretacija svagdašnjeg iskustva te biti okidač za ljudsku kreativnost bilo kojega oblika, uključujući tu i književnost.

Nikada, ali baš nikada, ne percipiramo stvarnost neposredno. Možda ne bismo tako mislili prije stotinjak godina, prije artikuliranja jedne od najzagonetnijih znanstvenih teorija ikada - kvantne teorije. Međutim, danas, kada znamo da se prema stvarnosti ne možemo odnositi jednako na makro- i mikro- skali, shvaćamo da nas samo naša stvaralačka moć konceptualizacije može dovesti do njezina poimanja koja se slažu s opažanjima. Osim toga, ovim se radom predlaže da se princip jedinstva 
materije, ponikao u okrilju kvantne teorije, uzme i kao polazište za uspostavu principa jedinstva znanosti, odnosno svih njezinih područja, a koja su danas poprilično međusobno udaljena, s ciljem njihova ponovnoga, ali ovoga puta i prijeko potrebitoga zbližavanja.

\section{Literatura}

Ashby, Ross W. 1958. Requisite variety and its implications for the control of complex systems. Cybernetica 1/2, 83-99.

Cornelius, Ian. 2003. Theorizing Information for Information Science. Annual Review of Information Science and Technology 36, 392-425.

doi:10.1002/aris.1440360110.

Culler, Jonathan. 2001. Književna teorija - vrlo kratak uvod. Zagreb: AGM.

Derrida, Jacques. 1976. O gramatologiji. Sarajevo: IP „Veselin Masleša“.

Derrida, Jacques. 2007. Pisanje i razlika. Sarajevo: Šahinpašić.

Dodig-Crnkovic, Gordana. 2014. Info-computational constructivism and cognition. Constructivist Foundations 9/2, 223-231. URL: http://constructivist.info/9/2/223.dodig.

Foerster, Heinz von. 1984. Observing Systems. The Systems Inquiry Series, Intersystems Publications, California.

Foerster, Heinz von. 2003. Understanding understanding: essays on cybernetics and cognition. Springer, New York.

Glasersfeld, Ernst von. 1995. Radical constructivism: a way of knowing and learning. Falmer Press, Taylor \& Francis Inc., Bristol, UK.

Heisenberg, Werner. 1997. Fizika i filozofija. Zagreb: Kruzak.

Heisenberg, Werner. 1998. Promjene u osnovama prirodne znanosti. Zagreb: Kruzak.

Krivak, Marijan. 2012. Suvremenost(i): postmoderno stanje filozofije (kulture)... i filma. Osijek: Sveučilište Josipa Jurja Strossmayera, Filozofski fakultet.

Maturana Humberto; Varela, Francisco. 1980. Autopoiesis and cognition: the realization of the living. Reidel, Dordrecht.

Miščević, Nenad. 1981. Filozofija jezika. Zagreb: Naprijed.

Nöth, Winfried. Priručnik semiotike. Zagreb: Ceres: 2004.

Oraić Tolić, Dubravka. 2011. Akademsko pismo. Zagreb: Naklada Ljevak.

Paić, Žarko. 2003. Za kritiku razlika. Europski glasnik 8, 37-64.

Qvortrup, L. 1993. The controversy over the concept of information. Cybernetics \& Human Knowing 1/4, 3-24. 
Segal Lynn. 2001. The dream of reality: Heinz von Foerster's constructivism. Springer Science+Business Media, New York.

Vukelja, Tihomir. Nesjedinljivo znanje. Zagreb: Kruzak, 2004.

Wersig, Gernot. 1997. Information theory. U: Encyclopaedic Dictionary of Library and Information Science. J. Feather \& P. Sturges, ur. London: Routledge, 220-227. 


\title{
WHY DOES OUR EXPERIENCE START FROM THE MIDDLE? ON THREE “MEDITATIONS ON THE MEDIATED EXPERIENCE"
}

\begin{abstract}
Boris BOSANČIC

Josip Juraj Strossmayer University of Osijek

Faculty of Humanities and Social Sciences

Lorenza Jägera 9, HR - 31000 Osijek, Croatia

bbosancic@ffos.hr
\end{abstract}

From a particular point of view that engages in several areas of human knowledge and activity, the paper attempts to trace possible sources of our experience based on signs and their interrelationships, as well as the process of attributing meaning. The main thesis of the paper is that our experience starts from the middle, and as such, it is always mediated, either by signifiers, as suggested by Jacques Derrida's poststructuralist theory on writing, or by the process of attributing meaning according to Heinz von Foerster's constructivist approach to the cognitive process, or by means of the signified as an occurrence that is generated in experiments of quantum physics only by the very act of observation, presupposed by the philosophical implications of the quantum theory by Werner Heisenberg.

Keywords: Sign, signifier, signified, poststructuralism, Jacques Derrida, constructivism, Heinz von Foerster, quantum theory, Werner Heisenberg 